\title{
Morphological detection of X- and Y-chromosomes in smears and paraffin-embedded tissues using a non-isotopic in situ hybridization technique (NISH)
}

Received: 17 January 1994 / Received in revised form: 26 April 1994

\begin{abstract}
Pharyngeal smears and paraffin-embedded tissue specimens (skeletal muscle, kidney) obtained from 10 male and 10 female individuals were evaluated using non-isotopic in situ hybridization (NISH) with commercial $\mathrm{X}$ - and Y-specific biotinylated probes which recognize the pericentromeric regions DXZ1 and DYZ1/DYZ3 of the $\mathrm{X}$ - and $\mathrm{Y}$-chromosome, respectively. The results provide evidence that the morphological sex determination of a single cell can be performed by critical application of this staining method leading to one nuclear signal in "male" cells using the Y-specific probe whereas "female" cells are negative. In situ hybridization of "female" tissues with an X-specific probe results regularly in 2 signals whereas "male" cells show only one spot in the nucleus.
\end{abstract}

Key words In situ hybridization - Sex determination

Zusammenfassung Es wurden Rachenabstriche sowie Paraffin-eingebettetes Leichengewebe (Skelettmuskel, Niere) von jeweils 10 männlichen und 10 weiblichen Individuen nach nicht-radioaktiver In-Situ-Hybridisierung (NISH) mit zentromerspezifischen X- und Y-Chromosom-spezifischen biotinylierten DNA-Sonden, die an die DXZ1- bzw. DYZ1/ DYZ3 Region der Geschlechtschromosomen binden, ausgewertet. Die Ergebnisse belegen, daß mit dieser Technik eine morphologische Geschlechtsbestimmung prinzipiell anhand der Auswertung einer einzigen Zelle möglich ist, wobei nach Applikation der Y-Chromosom-spezifischen Sonde in Zellen männlichen Kerngeschlechts ein nukleäres Signal erkennbar ist, während,,weibliche" Zellen negativ reagieren. Die In-Situ-Hybridisierung mit X-Chromosom-spezifischer Sonde ergibt in Zellen weiblichen Kerngeschlechtes zwei im Zellkern abgrenzbare Reakti-

P. Betz (四) · J. Tübel · W. Eisenmenger

Department of Legal Medicine, University of Munich,

Frauenlobstrasse 7a, D-80337 Munich, Germany

G. Baretton - A. Nerlich

Department of Pathology, University of Munich,

Frauenlobstrasse 7 a, D-80337 Munich, Germany onssignale, in „männlichen“ Zellen hingegen nur ein Signal.

Schlüsselwörter In-Situ-Hybridisierung

Geschlechtsbestimmung

\section{Introduction}

Sex determination of cells is of great importance especially in the investigation of biological stains or smears.

In addition to the detection of Barr or $\mathrm{Y}$ bodies by staining with Acriflavin or Quinacrin [2, 3, 6, 9-12] and an identification of X-and Y-chromosomes by dot-blot hybridization or polymerase chain reaction techniques $[1$, $4,5]$, the morphological detection of sex-specific chromosomes in interphase nuclei has been described [7, 8, 13]. The present study reports on a NISH technique using centromere-specific biotinylated DNA probes for chromosomes $\mathrm{X}$ and $\mathrm{Y}$ in smears and paraffin sections.

\section{Materials and methods}

Pharyngeal smears from 10 males and 10 females as well as skeletal muscle and kidney specimens from 10 male and 10 female corpses (postmortem interval less than 2 days, individual age between 20 and 40 years) were investigated.

For in situ hybridization commercial centromere-specific DNA probes binding to the DXZ1- or the DYZ1/DYZ3-region of the human X- or Y-chromosome respectively were used (Fa. Oncor/ Amersham Buchler, Braunschweig, Germany).

The freshly obtained smears were air-dried and after a short fixation in 5\% PBS-formaldehyde solution the endogenous peroxidase activity was inhibited by $\mathrm{H}_{2} \mathrm{O}_{2}$ /methanol. The smears were immersed in sodium thiocyanate (Fa. Sigma, Deisenhofen, Germany) for 5 mins $\left(80^{\circ} \mathrm{C}\right.$ ) and then enzymatically pretreated with proteinase K $(0.5 \%, \mathrm{Fa}$. Sigma, Deisenhofen, Germany) for 5-60 mins at room temperature. After washing in distilled water the slides were treated with $4 \%$ paraformaldehyde solution for $10 \mathrm{~min}$ and subsequently dehydrated in a series of increasing alcohol concentrations. The concentration of the X- or Y-specific biotinylated probes was $0.4 \mu \mathrm{g} / \mu \mathrm{l}$ in a solution containing formamide, herring sperm DNA (Fa. Sigma, Deisenhofen, Germany) and SSC (NaCl and sodium citrate). The smears were incubated overnight at $37^{\circ} \mathrm{C}$, 
Fig. 1 Male individual, in situ hybridization using a Y-chromosome specific DNA-probe: only one nuclear signal (see arrows) in parenchymatous cells of the kidney (paraffin, indirect peroxidase-method, $940 \times)$

Fig. 2 Female individual, in situ hybridization using a $X$ chromosome specific DNAprobe: 2 distinct signals (see arrows) in the nuclei of cells of the kidney (paraffin, indirect peroxidase-method, $940 \times$ )
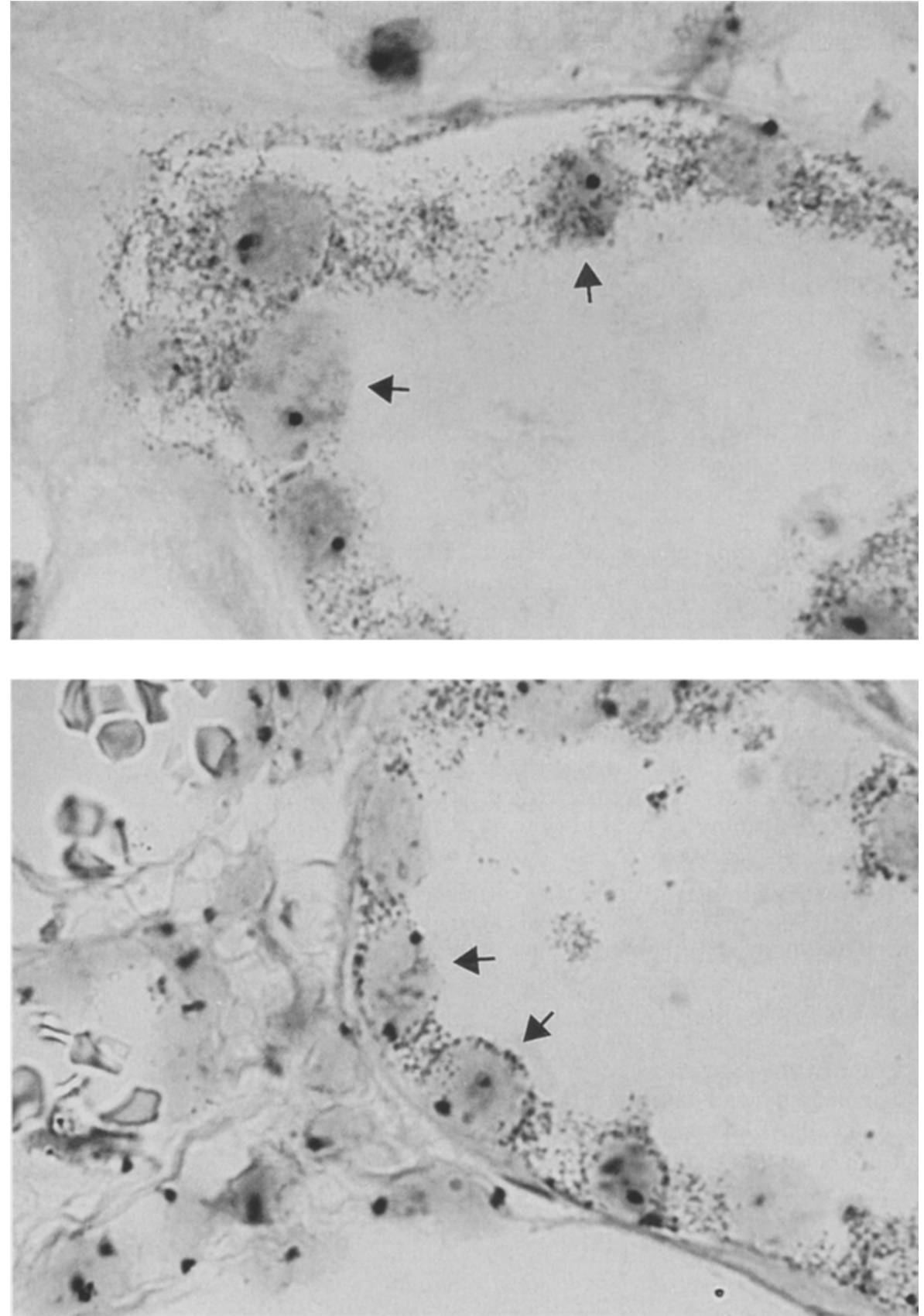

post-hybridization washings were performed with SSC. Immunohistochemical detection was carried out according to an indirect peroxidase-technique using DAB (Fa. Dako, Hamburg, Germany) as the chromogene. Counterstaining was performed with Harris' Haemalaun (Fa. Sigma, Deisenhofen, Germany). The tissue specimens obtained at autopsy were fixed in $4 \%$ PBS-formaldehyde solution, embedded in paraffin by routine methods and sections ( 6 $\mu \mathrm{m}$ ) were deparaffinized in xylol. Subsequently the sections were treated and stained as described above.

\section{Results}

Smears

After in situ hybridization with the X- or Y-specific probe, "male" pharyngeal cells showed one dark brown nuclear signal which could be unambiguously distinguished from black spot-like artefacts such as dust particles on the microscope slides. "Female" cells revealed no positive staining for the Y-specific DNA probe. Conversely 2 signals could be observed in most of these cells after in situ hybridization with the X-specific probe. In some of the "female" cells only one X-signal was found. This observa- 
tion, however, can easily be explained by unfavourable positions of the cells on the microscope slide leading to the detection of only one of the two topographically separate $\mathrm{X}$-chromosomes.

Positive results were observed in smears where an optimal enzymatic pretreatment could be performed while negative results were obtained in cells with an intact structure of the nucleus due to unsufficient enzymatic pretreatment. Aggressive enzymatic digestion, however, led to a considerable swelling or partial destruction of the nuclei and resulted in negative or unspecific signals independent of the probes used.

Smears without application of the specific DNA probes were treated correspondingly and acted as controls. None of these specimens showed positive nuclear signals.

\section{Paraffin-embedded tissues}

Similar results to the staining pattern observed in the pharyngeal smears were obtained for "male" cells of skeletal muscle and kidney including connective tissue cells and vascular endothelium with only one nuclear signal following in situ hybridization with X-or Y-specific probes (Fig. 1). In cells of specimens obtained from female corpses 2 signals were found using the X-chromosome specific DNA probe (Fig. 2) whereas in situ hybridization with the Y-specific DNA probe revealed to nuclear staining products. Negative or unspecific results were observed under the same conditions as in the pharyngeal smears. The evaluation of the paraffin sections, however, was more problematic since the cell borders of the parenchymatous cells were sometimes barely discernable so that the localization of a positive signal was much more difficult than in smears with topographically separate epithelial cells.

\section{Discussion}

The morphological sex determination of tissues, biological stains and smears by the detection of Barr- or Y-bodies in the nuclei after staining with Acriflavin or Quinacrin $[2,9,10]$ provide positive results only in a certain percentage of cells - depending on the tissue evaluated and unspecific signals have also been observed in cells of contrary nuclear sex in spite of optimal reaction conditions $[2,3,9,11]$. Recently, in situ hybridization techniques have been described using biotinylated or fluoresceine conjugated X-or Y-chromosome specific probes [7, $8,13]$. As shown in the present study, these methods can be applied to forensic problems by evaluation of smears or paraffin-embedded tissues.

However, some special requirements must be observed. Thus, it must be emphasized that if the enzymatic pretreatment is too aggressive the nuclear morphology can be destroyed whereas negative results are obtained if the pretreatment is too weak. Therefore, precise controls - including internal controls - are required. Furthermore, the evaluation of paraffin sections obtained from parenchymatous tissues post mortem in particular is sometimes difficult when the nuclear borders cannot be detected due to overlapping of the nuclei or to aggressive enzymatic pretreatment. This could lead to misinterpretation since it cannot always unambiguously be decided in which nucleus the detected signal is present. Therefore, only nuclei of clearly distinguishable single cells should be analyzed for sex determination. Consequently, such a diagnosis should, if possible, be based on a large number of cells though the nuclear sex determination may theoretically be performed by evaluation of a single cell.

Acknowledgements The authors thank Mrs. K. Schneiderbanger for technical assistance.

\section{References}

1. Akane A, Seki S, Shiono H, Nakamura H, Nasegawa M, Kagawa M, Matsubara K, Nakakori Y, Nagafuchi S, Nakagome Y (1992) Sex determination of forensic samples by dual PCR amplification of an X-Y homologous gene. Forensic Sci Int 52: $143-148$

2. Berghaus G, Reifenberg U, Dotzauer G (1973) Sex determination on skeleton parts [Geschlechtsbestimmung an Skeletteilen]. Z Rechtsmed 72:255-268

3. Brinkmann B, Jobst U (1973) Sex determination in biological stains [Bestimmung des Kerngeschlechts an biologischen Spuren]. Z Rechtsmed 73:1-6

4. Fukushima A, Hasekura H, Nagai K (1988) Identification of male bloodstains by dot hybridization of human Y-chromosome-specific DNA probe. J Forensic Sci 33:621-627

5. Gill P (1987) A new method for sex determination of the donor of forensic samples using a recombinant DNA probe. Electrophoresis $8: 35-38$

6. Given BW (1976) Sex-chromatin bodies in penile washings as an indicator of recent coitus. J Forensic Sci 21:381-386

7. Griffin DK, Wilton LJ, Handyside AH, Winston RML, Delhanty JDA (1992) Dual fluorescent in situ hybridization for simultaneous detection of $\mathrm{X}$ and $\mathrm{Y}$ chromosome-specific probes for the sexing of human preimplantation embryonic nuclei. Hum Genet 89:18-22

8. Pfitzinger H, Ludes B, Mangin P (1993) Sex determination of forensic samples: coamplification and simultaneous detection of a Y-specific and a X-specific DNA sequence. Int J Leg Med $105: 213-216$

9. Schwinger E (1972) Sex determination of blood traces [Geschlechtsbestimmung aus Blutspuren]. Z Rechtsmed 70:157162

10. Tröger HD, Eisenmenger W (1977) Eine Methode zum Nachweis von Scheidenepithelien. Beitr Gerichtl Med 35:109-111

11. Tröger HD, Eisenmenger W, Baur C (1980) Die Bedeutung der Y-chromosmalen Kerngeschlechtsbestimmung in der forensischen Spurenkunde. Beitr Gerichtl Med 38:259-261

12. Tröger HD, Baur C, Tutsch-Bauer E (1982) Vergleichende Untersuchungen zur Bestimmung des weiblichen und männlichen Kerngeschlechtes an Haaren. Beitr Gerichtl Med 40:229-232

13. Tyler MG, Kirby LT, Wood S, Vernon S, Ferris JAJ (1986) Human blood stain identification and sex determination in dried blood stains using recombinant DNA techniques. Forensic Sci Int $31: 267-272$ 